\title{
An Evaluation of the Factors that Impact on the Effectiveness of Blended E-Learning within Universities
}

\author{
Beatrice Aguti \\ School of Electronics and \\ Computer Science, University of \\ Southampton, \\ Southampton, United Kingdom \\ beatrice.aguti@gmail.com
}

\author{
Gary B Wills \\ School of Electronics and \\ Computer Science, University of \\ Southampton, \\ Southampton, United Kingdom \\ gbw@ecs.soton.ac.uk
}

\author{
Robert J Walters \\ School of Electronics and \\ Computer Science, University of \\ Southampton, \\ Southampton, United Kingdom \\ rjw1@ecs.soton.ac.uk
}

\begin{abstract}
Since the inception of e-learning technologies, there has been an increase in the use of e-learning systems to support blended learning in Universities by providing a mix of face-to-face classroom teaching, live e-learning, self-paced e-learning and distance learning. Despite the existing benefits of using e-learning, some higher education institutions have not utilized e-learning to its full potential and yet there are limited studies that offer a comprehensive framework for effectively using e-learning systems. It is therefore imperative that learning technologists understand the factors that influence the effectiveness of blended e-learning. An expert survey was conducted to establish which factors are important for evaluating the effectiveness of e-learning systems. This paper describes a methodological framework consisting of factors necessary for assessing the effectiveness of e-learning within Universities.
\end{abstract}

Keywords-Blended; E-learning; Effectiveness; Evaluation; Universities

\section{INTRODUCTION}

In the wake of the $20^{\text {th }}$ Century, there has been a paradigm shift in the education offered by higher education institutions of learning with the emergence of Electronic learning (hereafter e-learning). In [8] define e-learning as the use of technology to support and enhance learning practice. Consequently, the adoption of e-learning technologies has impacted the planning, learning design, management and administration of the learning process and delivery of learning content to the students [9] thereby promoting blended e-learning. Blended e-learning in Higher Education Institutions such as Universities currently encompasses the use of a mix of improved course delivery strategies during face-to-face classroom teaching with live e-learning, self-paced e-learning which are facilitated by Virtual Learning Environments. Such environments include learning management systems such as Moodle, WebCT, Blackboard as well Web 2.0 technologies which have become enablers for collaborative learning amongst students and lecturers, online discussions and distance learning. Over $80 \%$ of HEIs in the developed world are actively engaging in the use of e-learning systems for supporting their teaching and learning, with $97 \%$ of Universities reported to be using one or more forms of VLE [4].

On the other hand, Universities in developing countries especially sub-Saharan Africa are progressively adopting these e-learning technologies for teaching, research and supporting students' learning so as to reap the same benefits harnessed by the developed economies. However, education in sub-Saharan Africa are grappling with the continuing economic downturn, high demand for higher education in emerging knowledge-driven economies as well as inadequate availability of experienced and skilled teachers [17]. There is a need to improve on the quantity and quality of teachers in order to meet the high demand for education. Universities in subSaharan Africa are also still facing numerous challenges such as high volume of students, limited ICT infrastructure, high illiteracy levels, ineffective computer system maintenance and poor ICT support relative to the implementation of e-learning [15].

E-learning has grown to complement traditional classroom-based learning [3] by combining the use of technology with effective pedagogy and reflective teaching thereby transforming higher education. 
Besides, e-learning in higher education may be used as a resource to provide online student and instructor support, online student management, and provision of formative and summative assessment feedback to the students. Currently, the greatest attention is on assessing effectiveness of e-learning systems within HEIs [1].

Although e-learning has become a household word amongst many academics in Universities from both developed and developing countries, there is still inadequate research focusing on the development of a comprehensive model to define, assess and measure the effectiveness of blended e-learning so as to deal with the aforementioned challenges. In [5] it is argued that e-learning developers and practitioners are preoccupied with advancing e-learning technologies towards desired quality of e-learning systems rather than providing leverage to the teaching and learning processes. However, there are limited studies focusing on the development of an holistic solution for evaluating the effectiveness of current blended e-learning strategies. To ensure effective blended e-learning, we propose a framework that focuses on having a well balanced mix of effective pedagogy in e-learning course design and delivery, apt institutional readiness for e-learning and use of quality e-learning systems to meet institutional and student learning goals. These are important aspects of evaluating blended e-learning effectiveness, once used as a tool, it will inform decisions made by policy makers, Universities and Governments thus influencing an increase in; rate of graduation, student retention, enrolment levels, return on investment, institutional recognition, and academic achievement [7] as well as improving the performance and quality of teachers, research and education.

\section{E-LEARNING AND EFFECTIVENESS OF BLENDED E-LEARNING IN UNIVERSITIES}

In a University consisting of undergraduate degree programmes, postgraduate programmes such as Certificates, Diplomas, Taught Masters, Masters by research, and $\mathrm{PhD}$ degrees, typical stakeholders of e-learning include: Students, E-learning experts, E-learning system developers, learning technologists, and Lecturers [3]. In [9], e-learning systems architecture offers a view of all design elements and functions such as functionality, usability and aesthetics that ought to be integrated in any elearning system. This is a prerequisite of any system development team to engage adequately in requirements elicitation and analysis for the intended system in order to identify its processes, functionality, interface and benefits. Systems design also being a vital aspect of system development must ensure that the predominant principles of system design are followed. In [9], these principles are listed as; open architecture, scalability, global, integration, flexibility, rapidness and timeliness.

An e-learning framework comprising eight dimensions was developed and described in [6] namely; pedagogical, technological, interface design, evaluation, management, institutional, resource support, and ethical shown in table 1. This e-learning framework offers a platform that enhances the success of the learner's experience once completely embraced by higher education institutions.

\section{A. Evaluation of E-Learning in HEIs}

In their empirical investigation, [12] sought to validate their methodological framework, focused on measurement of students' perceived satisfaction with the learning management system in higher education context relative to six dimensions of the hexagonal model. These six dimensions in the proposed hexagonal e-learning assessment model included; service quality, system quality, content quality, learner perspective, instructor attitude and supportive issues. Their results showed that there was a close relationship between students' perceived satisfaction and each of the six dimensions of the Hexagonal model. In [2], a learning design methodology was proposed, focused on the design, development and evaluation of distance-learning services that are webbased learning design for adult computer science courses. The framework was based on three main evaluation axes, namely; (1) Information and support provided to learners at the beginning of and during their studies, (2) the learner's performance and (3) the learner's satisfaction. The results showed that the tutors' presence played a significant role in extending support towards the students' accomplishment of the web-based course because of the pedagogical approach to support students. Students judged their satisfaction with the web-based course design on the basis of: enjoyment, benefits, content, adequacy and applicability. In this case, the students were satisfied with the web-based course which greatly impacted on their performance. The students' perceived performance was high as they had great expectations to acquire knowledge and skills, although they were challenged with maintaining their motivation.

As a result, variables were identified from these frameworks to guide the process of developing the proposed framework for evaluating the effectiveness of blended e-learning. These frameworks focus on the impact of quality e-learning systems on students' perceived satisfaction and achievement which 
constitutes only part of criteria for assessing the effectiveness of blended e-learning. In this paper, we propose a comprehensive framework for evaluating the effectiveness of blended e-learning within Universities.

\section{STUDY APPROACH}

An expert evaluation survey was conducted to confirm the components to be included the framework. A total of 16 experts were contacted from Universities in Europe, Africa and Asia. Among these were Assistant lecturers, Lecturers, Senior lecturers, Professors, E-learning experts and E-learning developers, later categorized as e-learning educationalist or e-learning technologist as shown in figure. Their experiences were taken based on their use of ICT and web technologies within Universities. These experts were required to rate the importance of each of the variables for assessing effective blended e-learning.

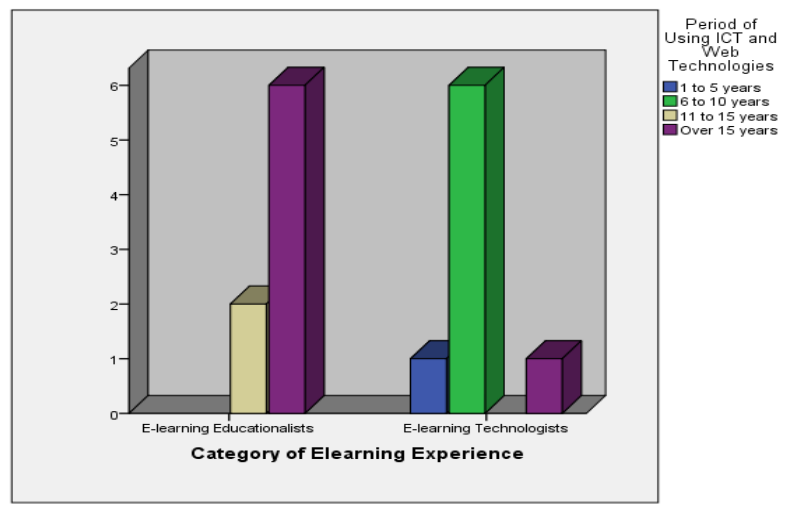

Figure 1. E-learning Expert Experience in the use of ICT and Web Technologies

\section{FRAMEWORK FOR EVALUATING THE EFFECTIVENESS OF BLENDED E-LEARNING}

The established theories, models, frameworks and prior research findings, have influenced the development of the proposed framework which suggests that effectiveness of blended e-learning can be determined by evaluating four (4) main dimensions, namely E-learning Readiness, E-learning Course Delivery Strategies, Quality E-learning Systems and Effects of Blended E-learning. The interactions between these dimensions are illustrated in figure 1. E-learning Readiness in terms of costing and budgeting, policies, support, cultural awareness, and infrastructure have an influence on the quality of e-learning systems and e-learning course delivery strategies, which in turn have an impact on the effectiveness of blended e-learning.

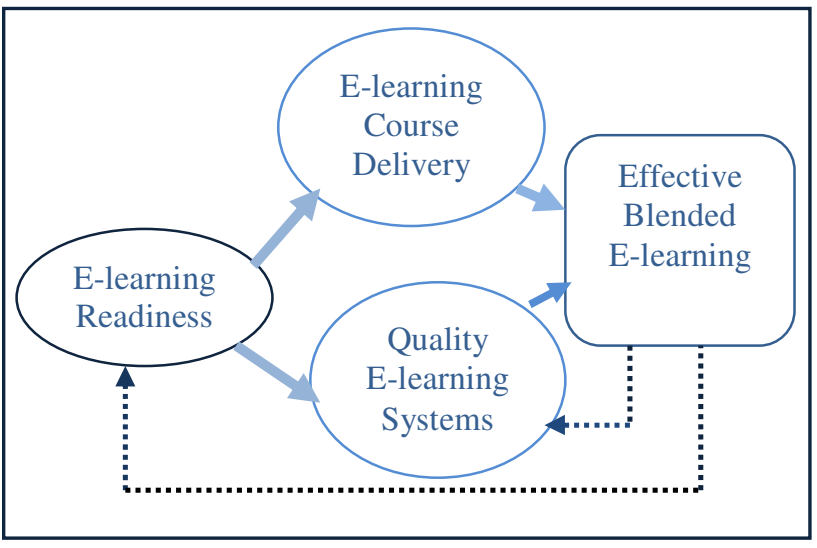

Figure 2. Proposed framework for evaluating the effectiveness of blended e-learning within Universities

The aim of the proposed framework is to aid; understanding of factors influencing the effectiveness of blended e-learning and measure the level of effectiveness of blended e-learning in Universities. The relationship between the dimensions, components in the framework are shown in table 2. A total of 67 items were created, with 23 items for Course Module Design Strategies dimension, 24 items for E-learning Readiness dimension, 15 items for Quality E-learning Systems dimension, and 7 items for Effective Blended E-learning.

TABLE I. A SYNTHESIZED LIST OF DIMENSIONS, COMPONENTS AND ITEMS FOR MEASURING FOR ASSESSING ELEARNING READINESS, E-LEARNING COURSE DELIVERY STRATEGIES, QUALITY OF E-LEARNING SYSTEM AND EFFECTIVE BLENDED E-LEARNING

\begin{tabular}{|c|c|c|}
\hline Dimension & Component & Item \\
\hline \multirow{15}{*}{$\begin{array}{l}\text { E-learning } \\
\text { Course } \\
\text { Delivery } \\
\text { Strategies }\end{array}$} & \multirow{6}{*}{$\begin{array}{l}\text { Course Module } \\
\text { Layout }\end{array}$} & Course module outline \\
\hline & & Course module prior knowledge \\
\hline & & Course module understandable \\
\hline & & $\begin{array}{l}\begin{array}{l}\text { Course module progression } \\
\text { levels }\end{array} \\
\end{array}$ \\
\hline & & $\begin{array}{lll}\begin{array}{l}\text { Course } \\
\text { outcomes }\end{array} & \text { module } & \text { learning } \\
\end{array}$ \\
\hline & & Course sequentially organised \\
\hline & \multirow{7}{*}{$\begin{array}{l}\text { Course Module } \\
\text { Evaluation }\end{array}$} & Course module alignment \\
\hline & & Course module requirements \\
\hline & & Course module periodic updates \\
\hline & & Course module resources \\
\hline & & Course module expectations \\
\hline & & Course module difficulty \\
\hline & & Course module teaching quality \\
\hline & & Randomised online assessments \\
\hline & & Knowledge \\
\hline
\end{tabular}




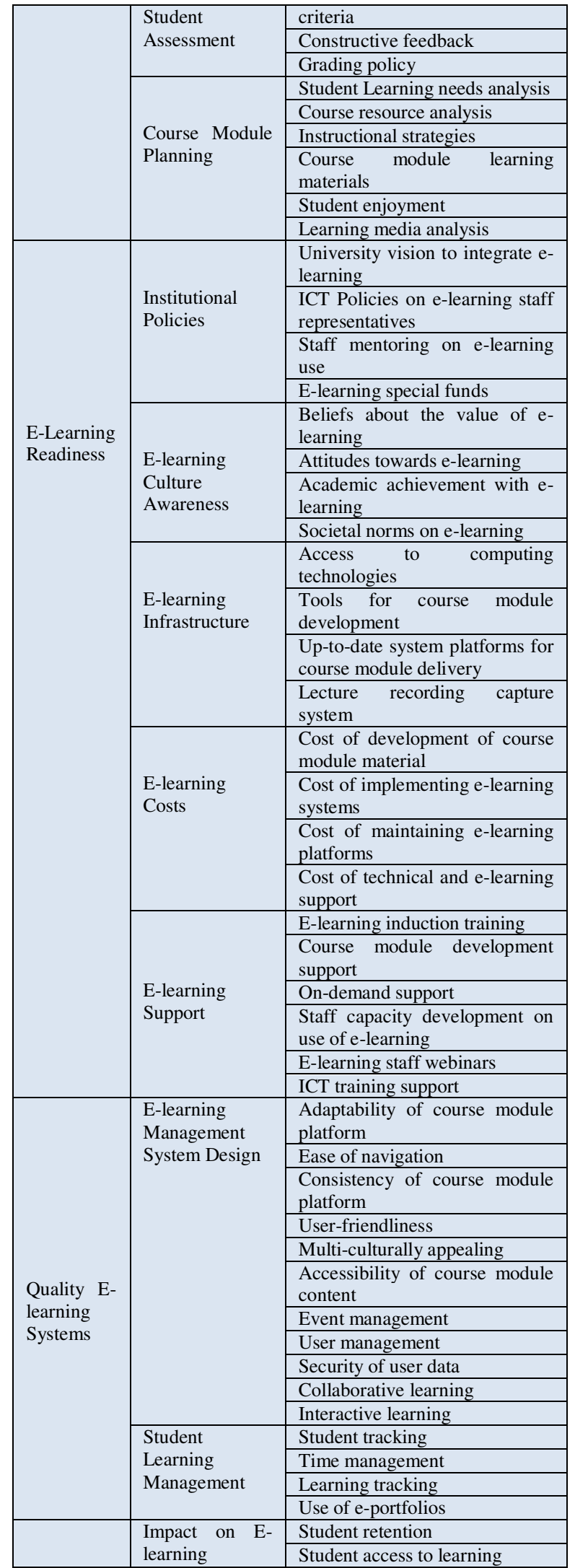

\begin{tabular}{|l|l|l|}
\hline \multirow{3}{*}{$\begin{array}{l}\text { Effective } \\
\text { Blended }\end{array}$} & Readiness, Quality of E- & Cost effectiveness \\
E-Learning & learning & Performance and quality of \\
& Systems and E- & lecturers \\
\cline { 3 - 3 } & learning Course & Academic achievement \\
\cline { 3 - 3 } & Module & Improvement of research and \\
& Delivery & \\
& Strategies & \\
\hline
\end{tabular}

\section{DISCUSSION}

On average, the e-learning educationalists agreed more to the factors in the framework $(\mathrm{M}=3.5287, \quad \mathrm{SE}=.1612) \quad$ than the e-learning technologists $(\mathrm{M}=3.1086, \quad \mathrm{SE}=.05644) . \quad$ The difference was not significant $\mathrm{t}(14)=2.45$, p.>.05. as shown in table II and III.

TABLE II. INDEPENDENT SAMPLE TEST MEANS

\begin{tabular}{rrrrrr}
\hline & $\begin{array}{r}\text { Category of Elearning } \\
\text { Experience }\end{array}$ & $\mathrm{N}$ & Mean Std. Deviation & $\begin{array}{r}\text { Std. Error } \\
\text { Mean }\end{array}$ \\
& & & & & \\
\hline $\begin{array}{r}\text { Factors for Effective } \\
\text { Blended E-learning }\end{array}$ & $\begin{array}{r}\text { E-learning } \\
\text { Educationalists }\end{array}$ & 8 & 3.5287 & .45597 & .16121 \\
\cline { 2 - 6 } & E-learning Technologists & 8 & 3.1086 & .15965 & .05644 \\
\hline
\end{tabular}

TABLE III. INDEPENDENT SAMPLE T-TEST

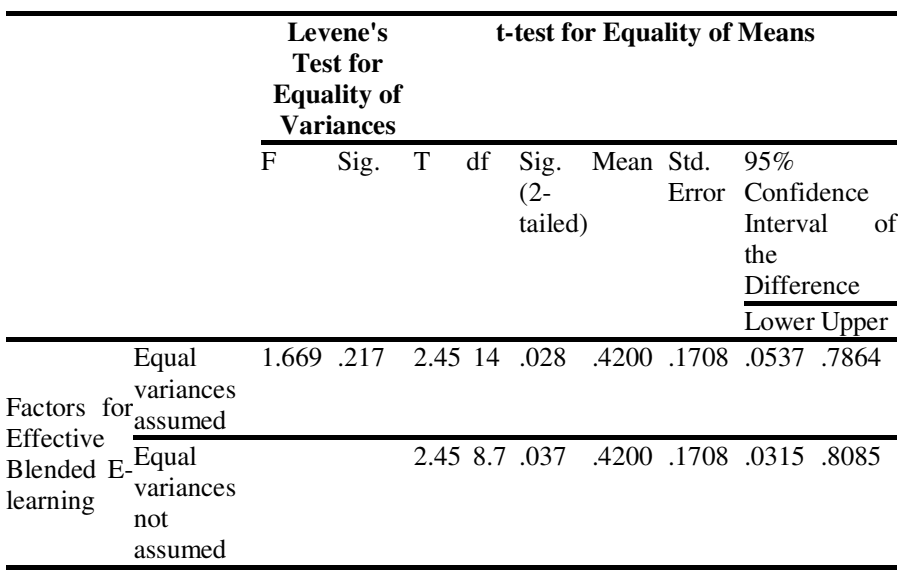

\section{CONCLUSION}

The main challenge for HEIs is to find a model that can used to evaluate the effectiveness of blended e-learning within Universities. In a bid to address this challenge, a pilot study will be conducted to further investigate the drivers and effects of blended e-learning within Universities. This framework acts 
as an instrument to be used to conduct an explorative study to facilitate stakeholders like University administrators, lecturers, e-learning experts, policy makers and Government in their decision making processes. These processes involve constant monitoring and evaluation of blended e-learning strategies to ensure that we derive an effective institutional outcome.

\section{REFERENCES}

[1] Andersson, A. (2008). Seven major challenges for elearning in developing countries: case study eBIT, Sri Lanka. International Journal of Education and Development using Information and Communication Technology, 4 (3), 45-62.

[2] Antonis, K., Daradoumis, T., Papadakis, S. \& Simos, C. (2011). Evaluation of the Effectiveness of a Webbased Learning Design for Adult Computer Science Courses. IEEE Transactions on Education, 54 (3), 374-380.

[3] Arabasz, P., Pirani, J. A. \& Fawcett, D. (2003). Supporting E-Learning in Higher Education. EDUCAUSE Center for Applied Research.

[4] Britain, S. \& Liber, O. (2003). A Framework for the Pedagogical Evaluation of Virtual Learning Environments. JISC. UK.

[5] Hughes, J., Katzeff, C., Abdallah, L., Scheuermann, F., Reich, K., Admiraal, W., . . Kuusinen, R. (2006). Evaluating E-learning. A Guide to the Evaluation of E-learning, Stanford, California, Creative Commons.

[6] Khan, B. H. (2010). The Global Elearning Framework. Elearning.

http://webserver.ignou.ac.in/institute/STRIDE_Hb8_w ebCD/Chapter\%205.pdf.

[7] Kirkpartick, D. L. (1994). Evaluating Training Programs, San Francisco, Berrett-Koehler Publishers, Inc.

[8] Mayes, T. \& De Freitas, S. (2005). JISC e-Learning Models Desk Study. Stage 2: Review of e-Learning theories, frameworks and Models Joint Information Systems Committee.

[9] Namahn. (2010). E-learning. Available: http://www.namahn.com/resources/documents/note-elearning.pdf [Accessed 27th April, 2012].

[10] Olds, B. M. (2002). Effective Strategies to Assess the Impact of e-Learning.Conference on e-Technologies in Engineering Education: Learning Outcomes Providing Future Possibilities, 2002. Davos, Switzerland.

[11] Ozkan, S. \& Koseler, R. (2009). Multi-Dimensional Evaluation of E-Learning Systems in the Higher Education Context: An Empirical Investigation of a Computer Literacy Course.ASEE/IEEE Frontiers in Education, 2009. San Antonio, TX. IEEE.

[12] Reiser, R. (2001). A History of Instructional Design \& Technology: Part 1: A History of Instructional Media. Educational Research \& Development, 49 (1), 53-64.

[13] Ssekakubo, G., Suleman, H. \& Marsden, G. (2011). Issues of Adoption: Have E-Learning Management Systems Fulfilled their Potential in Developing Countries? SAICSIT, 231-238.

[14] UNESCO (2006). Teachers and Educational Quality: Monitoring Global Needs for 2015. UNESCO Institute for Statistics, Montreal. Available: http://unesdoc.unesco.org/images/0014/001457/14575 4e.pdf. 